\title{
Principal's Strategies and Approaches to Perform Effective Academic Supervision
}

\author{
Kholid \\ $\left\{\right.$ kholid_66@yahoo.com $\left.{ }^{1}\right\}$ \\ SD 2 Medini, Jl. Kudus-Purwodadi Km.13 Undaan, Kudus, Indonesia
}

\begin{abstract}
Academic supervision is one of the main tasks of the principal. In practice, it is not uncommon for academic supervision to be conducted not following applicable regulations. This resulted in ineffective academic supervision activities. In carrying out effective academic supervision activities, principals need mastery of supervisory competencies and indicators. However, the principal still needs to have a strategy that is a standard educational process and approach to conducting academic supervision. Good academic supervision results allow principals and teachers to take the actions needed to overcome any academic problems that arise. Anticipatory anticipation and solutions to problems that are solutive allow educational activities in schools to run smoothly.
\end{abstract}

Keywords: principal's strategies and approaches, effective academic supervision

\section{Introduction}

The quality of education can be measured by the readiness of schools in addressing, understanding, and carrying out learning tasks and responsibilities. The principal as the leader in the school plays a very vital role in this matter. One of the strategies undertaken is to carry out the supervision of the school principal to monitor, foster, and improve teaching and learning in the classroom [1]. Academic supervision is one of the principal's duties which is intended to improve the quality of continuing education in schools [2].

Academic supervision activities are often found only formally to fulfill the reporting obligations of supervision. Principals tend to assess the structural conditions and completeness of documents alone, without the right approach, long-term, detailed, and problem-based aspects of sustainability [3]. Another problem that often arises is the lack of school supervisory competency. The principal lacks the ability to use a variety of supervisory techniques and strategies. Training and seminars on supervision of school principals are often held, but not a few principals only carry out supervision activities when instructed only or do not carry out supervision activities as they should [4].

This article main purpose is to spell out the strategies that the principal can do to carry out effective academic supervision. This article is expected to provide learning material and information to better understand the principal's academic supervision implementation strategies. Specifically for principals, this article is input and motivation to improve performance in leading and managing schools so that school goals are achieved effectively and efficiently. 


\section{Academic supervision}

\subsection{Definition of academic supervision}

Supervision consists of the word super (meaning above) and vision (meaning view). Supervision can be interpreted freely as a vision/view from above. The definition of supervision in general in the Cambridge Advanced Learner's Dictionary is the act of watching a person or activity and making certain that everything is done correctly, safely, etc. While the definition of supervision in the organizational context in the Cambridge Business English Dictionary is the activity of managing a department, project, etc. and of making sure that things are done correctly and according to the rules.

Supervision activities in the world of education are called academic supervision. Academic supervision is a series of activities in helping teachers develop their ability to manage the learning process to achieve learning objectives [2]. Academic supervision is a supervisory effort carried out by the principal to provide improvements and enhancements so that learning can be done well and of high quality. Educational supervision is a process of providing professional education services through continuous guidance to teachers and other school personnel to improve and enhance the effectiveness of personnel performance to achieve student growth [5].

Academic supervision activities in schools are generally carried out by the principal toward the teacher. Academic supervision in The Greenwood Dictionary of Education is explained as a process of validation, empowerment, and is part of work professionalism. Supervision activities include providing direction, regulation, and management, but do not fully control the situation. Commitment to high goals and standards is more easily realized when using shared professional norms than strict bureaucratic control. Some forms of academic supervision activities can be in the form of group discussions and peers' suggestions to a process that allows teachers to work independently and be able to supervise themselves [6].

Academic supervision can also be interpreted as a form of service, guidance, assistance, and supervision carried out by the principal to develop, improve, and improve the quality of teaching teachers. The assistance and guidance are professional in nature and are carried out through dialogue to solve learning problems. The principal as a supervisor has the task of assisting and fostering teachers to be more professional in carrying out their duties, functions, and obligations. Academic supervision is carried out in a planned, patterned, and the programmed manner in changing teacher behavior in order to improve the quality of the learning process. Supervision of the principal is important to be carried out to create social situations and conditions that can foster motivation and performance of teachers [7].

Academic supervision is a series of activities assisting teachers in developing the ability to manage the learning process. The intended capacity development is not only limited to increasing teacher knowledge and teaching skills. Capacity building also includes increasing teacher commitment, willingness, and work motivation. Improved learning management capabilities that are supported by high teacher work motivation can be expected to improve the quality of learning in general [2].

\subsection{The purpose of academic supervision}

Academic supervision programs are carried out to provide guidance and technical assistance to teachers in improving the quality of the learning process. Academic supervision 
activities are carried out technically to evaluate the quality of teacher performance in carrying out their duties and responsibilities as a professional educator. For principals, good academic supervision competencies can support principals' leadership in managing all school programs effectively and efficiently. For teachers, other than as a means of performance evaluation, academic supervision conducted by school principals can provide positive input for the development of teacher competencies [1].

The Ministry of National Education of the Republic of Indonesia had specifically formulated 3 (three) general objectives of the academic supervision program, namely:

(1) Professionalism development

(2) Quality control

(3) Growth of motivation

\subsection{Principal's academic supervision competencies}

The competency of the principal is inseparable from the main tasks and functions as the principal. Regulation of the Minister of Education and Culture of the Republic of Indonesia No. 6/2018 concerning the Assignment of Teachers as Principals defines competence as knowledge, attitudes, and skills inherent in the dimensions of personality, managerial, entrepreneurship, supervision, and social competence. The principal's academic supervision competency is the 4th competency. Academic supervision regulated in Regulation of the Minister of National Education of the Republic of Indonesia No. 13/2007 concerning Principal/Madrasah Standards, which includes planning, implementing, and following up on academic supervision results. Each dimension of supervision competency is further explained in the Supervision Competency Indicator in the Principal/Madrasah Competency Test.

\section{Competence 1}

Planning an academic supervision program in order to improve teacher professionalism.

a. Develop an academic supervision program.

b. Formulate stages of the technique of academic supervision.

c. Outlines the objectives of academic supervision in each of the scopes of the implementation and evaluation of learning.

d. Use an effective academic supervision approach.

e. Develop monitoring and evaluation procedures for academic supervision.

f. Formulate the criteria for achieving the objectives of academic supervision (output).

Competence 2

Implementing academic supervision of teachers using appropriate approaches and supervision techniques.

a. Carry out academic supervision based on the needs and real problems faced by the teacher.

b. Build relationships with teachers and all parties involved in supervision activities based on the principles of academic supervision.

c. Use academic supervision approaches and techniques that are appropriate and following the objectives of academic supervision.

d. Solve the problem of developing academic supervision learning.

e. Use information technology to support the effectiveness of academic supervision. 


\section{Competence 3}

Following up on the results of the academic supervision of teachers to improve teacher professionalism.

a. Formulate the criteria for achieving the effects of academic supervision (outcome).

b. Developing instruments for measuring the achievement of direct results (output) academic supervision.

c. Analyze the results of the evaluation for the benefit of follow-up.

d. Develop a follow-up program based on the results of an evaluation of academic supervision.

e. Determine clinical supervision steps.

A school principal is required to have good managerial skills as a leader in a school. The principal's competence in supervising is one of the abilities in the managerial dimension. Supervision activities carried out primarily on the activities, creativity, and performance of teachers. Competent principals will be able to carry out supervision effectively and efficiently to assist teachers in the learning process and can improve teacher performance [8].

\section{Effective academic supervision}

\subsection{The principle of academic supervision}

Academic supervision can be said to be effective if it can provide support, guidance, and coaching to teachers to be better in guiding learners and be able to improve teacher performance [9]. For maintaining effective academic supervision, the principal needs to understand the principles in conducting academic supervision activities. The application of these principles aims to create a good relationship between the principal, teachers, and other parties concerned. There are some principles of academic supervision set by the Ministry of National Education of the Republic of Indonesia to ensure effective academic supervision:

(1) Practical (it is easy to do according to school conditions)

(2) Systematic (it is developed according to the planning of a mature supervision program and learning objectives)

(3) Objective (input is the following aspects of the instrument)

(4) Realistic (based on actual reality)

(5) Anticipatory (being able to deal with problems that might occur)

(6) Constructive (developing the creativity and innovation of educators in developing the learning process)

(7) Cooperative (there is good cooperation between supervisors and educators in developing learning)

(8) Kinship (considering mutual, caring, and fostering in developing learning)

(9) Democratic (supervisors cannot dominate the implementation of academic supervision)

(10) Active (educators and supervisors must actively participate)

(11) Humanist (being able to create harmonious, open, honest, consistent, patient, enthusiastic, and humorous human relations)

(12) Continuity (academic supervision is carried out regularly and continuously by the school principal)

(13) Integrated (it is integrated with the education program)

(14) Comprehensive (it fulfills the three objectives of academic supervision) 


\subsection{Strategies for implementing effective academic supervision}

Academic supervision should be based on the results of the identification of the problems faced by teachers. Therefore, strategies for implementing effective academic supervision must be considered step by step. The main strategy is summarized in a standard educational process compiled by the Ministry of National Education of the Republic of Indonesia.

First, monitoring the learning process is carried out at the planning, implementation, and evaluation stages of learning outcomes. Monitoring is carried out through, among others, focus group discussions, observations, recording, recording, interviews, and documentation.

Second, supervision activities of the learning process are carried out at the planning, implementation, and evaluation stages of learning outcomes carried out through, for example, modeling, discussion, consultation, or reporting training.

Third, the results of the monitoring, supervision, and evaluation of the learning process are compiled in the form of a report for the benefit of continuing follow-up of the professional development of educators on an ongoing basis.

Final, following up on the results of supervision is carried out in the form of reinforcement and appreciation for teachers who demonstrate performance that meets or exceeds standards, and providing opportunities for teachers to take part in ongoing professional development programs.

\subsection{Approaches to perform effective academic supervision}

Schools as educational service provider institutions, ideally need to have qualified teachers. However, in reality, the abilities, conditions, and personalities of the teachers vary greatly. This requires a different approach to supervision strategy for each teacher and problem situation. There are 3 (three) approaches that can be applied in academic supervision [2], including:

(1) Direct approach (directive)

A direct approach is a strategic approach to the problem approach that is direct. The principal will give directives to educators. The direct approach has the consequence that the influence of the principal is more dominant during supervision. Generally, supervision with a direct approach is done face-to-face.

(2) Indirect approach (non-directive)

The indirect approach is the opposite of the direct approach and was chosen to overcome indirect problems. Principals tend to listen and provide reinforcement in the problemsolving process. The indirect approach can also be done through intermediary media, such as through correspondence, mass media, electronic media, radio, cassettes, internet, and so forth.

(3) Collaborative approach

The collaborative approach combines direct and indirect approaches into a new approach. Principals and teachers agree on the structure, process, and criteria for supervision.

Also, based on the dynamics of the academic supervision approach above, 2 (two) academic supervision concepts are known [2], namely:

(1) Class supervision

Class supervision is done as an effort to identify learning problems that occur in the classroom and develop alternative solutions. Class supervision is top-down which is technically determined by the school principal.

(2) Clinical supervision 
Clinical supervision is supervision based on the demand/needs of teachers. Clinical supervision is carried out because of problems that have not been completed in the implementation of classroom supervision. Clinical supervision is bottom-up which technically is determined by the implementation of authentic problems experienced by the teacher, and then it is used as a basis in the preparation of academic supervision programs.

\section{Conclusion}

This article is tried to show that to perform effective academic supervision, the principal needs to master the required academic supervision competencies and the indicators. Principals need adequate training to improve their managerial skills to ensure that academic supervision is conducted accordingly. Principals must adhere to applicable regulations related to academic supervision activities. The strategy that allows for effective academic supervision starts with the problems faced by each teacher in each school, which is then supervised to find solutions to their completion. Academic problems that have been solved are valuable experiences for teachers and principals in relation to developing their abilities through follow-up recommended from the findings of academic supervision until new problems are discovered.

The accuracy of the selection of approach strategies greatly determines the success of technical supervision activities. The choice of approach is determined by applying psychological principles. Therefore, principals need to hone their competence and sensitivity in determining the academic supervision approach.

\section{Acknowledgements}

The work on this article is supported by all teachers and staff at SD 2 Medini, Kudus Regency, Indonesia.

\section{References}

[1] Iwantoro.: Kompetensi Supervisi Kepala Sekolah Meningkatkan Kinerja Guru dalam Rangka Mencapai Tujuan Pendidikan. Jurnal At-Tajdid. Vol. 3, No. 2. pp. 53-65. (2014)

[2] Snae, Y. D. I., Budiati, A. C., and Heriati, T. 2016. Modul Kepala Sekolah Pembelajar Kelompok Kompetensi 10: Supervisi Akademik. Jakarta: Direktorat Jenderal Guru dan Tenaga Kependidikan Kementerian Pendidikan dan Kebudayaan.

[3] Ugurlu, C. T.: Current Problems in Terms of Supervision Process of School Principals' Views. Hacettepe Universitesi Journal of Education. Vol. 29, No. 3. pp. 184-196. (2014)

[4] Iroegbu, E. E. dan Etudor-Eyo, E.: Principals' Instructional Supervision and Teachers' Effectiveness. British Journal of Education. Vol. 4, No. 7. pp. 99-109. (2016)

[5] Engkoswara dan Komariah, A.: Administrasi Pendidikan. Alfabeta. (2011)

[6] Collins III, J. W. dan O'Brien, N. P. 2011. The Greenwood Dictionary of Education (2nd Edition). Westport: Greenwood Press.

[7] Rismawan, E.: Pengaruh Supervisi Kepala Sekolah dan Motivasi Berprestasi Guru terhadap Kinerja Mengajar Guru . Jurnal Administrasi Pendidikan, Vol. 22, No. 1. pp. 114-132. (2015)

[8] Mulyasa, E.:Manajemen dan Kepemimpinan Kepala Sekolah. Bumi Aksara. (2012) 
[9] Ajasan, Usman, N., and Niswanto.: Efektivitas Pelaksanaan Supervisi Akademik Oleh Kepala Sekolah Dalam Meningkatkan Kinerja Guru Di Smk Negeri 1 Meulaboh. Jurnal Administrasi Pendidikan. Vol. 4, No. 3. pp. 1-9. (2016) 